\title{
Study on the Operation Status for Academic Operation and Management for Graduate Schools in South Korea
}

\author{
Suk-Yeol Lee ${ }^{1}$ and Ho-Seub Lee ${ }^{2 *}$ \\ ${ }^{1}$ Professor, Division of General Education, Namseoul University, Cheonan, Korea \\ ${ }^{2}$ Professor, Division of General Education, Sookmyung Women's University, Seoul, \\ Korea \\ ${ }^{1}$ leesy@nsu.ac.krmail, ${ }^{2}$ smlhs@sookmyung.ac.kr
}

\begin{abstract}
This study aims to analyze the current status and actual conditions of the academic operation and management of general graduate schools. Graduate school in South Korea has grown rapidly in terms of numbers but the quality level is yet insufficient to meet the growing demands of society. This study analyzes how well graduate schools operate academic affairs and management, in order to improve the quality of graduate schools. The analysis was conducted on 106 (57.3\%) graduate schools out of a total of 185 graduate schools. The results of the study are as follows. The proportion of freshmen students in master's programs who completed their bachelors degree from the same university was $43.2 \%$, and the proportion of students who held bachelor degrees from a different university was $56.8 \%$. The required credits to complete a graduate program are approximately 24 to 26 credits for the master's program, 34 to 40 credits for the doctoral program, and 54 to 60 credits for the integrated master's and doctoral program. Approximately $94 \%$ of master's programs are operated in 4 semesters, and similarly $64 \%$ of the doctoral programs operate in 4 semesters (2 years), while about 24\% of the integrated master's doctoral programs operate in 6 semesters (3 years). Overall, the minimum attendance requirement for granting credits is either above two-thirds or three-quarters of the program, and these standards are mostly established by the graduate schools.
\end{abstract}

Keywords: Graduate school, Educational conditions, Educational support system, Academic operation, Academic management, Degree conferment system, CIPP model

\section{Introduction}

South Korea's graduate schools have achieved considerable quantitative expansion over the years. The number of graduate schools has increased from 64 in 1970 to 1,172 in 2018; by more than 18 fold. The number of enrolled students has also increased by 42 times from 6,640 in 1970 to 278,888 in 2018. However, despite such quantitative expansion, South Korean graduate schools are evaluated and deemed to have insufficient capacity and conditions for knowledge creation compared to advanced and developed countries [1][2][3][4].

The graduate school system in South Korea is largely classified into three types: general graduate school, vocational graduate school, and special graduate school. General graduate schools aim for 'basic theories of academic studies and advanced academic research'.

Article history:

Received (October 2, 2020), Review Result (November 4, 2020), Accepted (December 11, 2020)

JARR

Copyright (C) 2021 Global Vision Press (GV Press) 
Vocational graduate schools aim for 'application of practical theories and research \& development'. Special graduate schools aim for 'continued education for professionals and adults'. However, although these graduate school systems and structures exist separately, the contents and methods of education are not easy to distinguish in reality [1].

The government's financial support projects aimed to foster academic research in research universities and graduate schools. There is a need to examine whether Korean graduate schools are performing their roles and functions in line with these higher education policies. It has not yet been possible to comprehensively check the conditions and outcomes of education and research, and connect them with administrative and financial support in order to secure the quality of graduate school education [5][6][7]. Even now, it is necessary for graduate schools to faithfully operate academic management and to prepare measures to improve the quality of graduate school.

This study started with the need to prepare and promote a plan for graduate schools to faithfully operate academic management and improve the quality of graduate schools. In order to do this, an accurate grasp and analysis of the current state of graduate school operation is required [5][6][7][8][9][10]. Therefore, it is necessary to provide a balanced analysis of the current status of input, process, and output of graduate schools. Higher education policy proposals and suggestions need to be based on this foundation. The purpose of this study is to improve the quality of graduate schools by analyzing its academic operation and management.

\section{Research method}

The analysis of the academic operation and management of general graduate schools was completed in two stages. The first step analyzed the statistics of students attending general graduate schools based on the data from the University Information Disclosure System. Since 2008, South Korea launched the University Information Disclosure System to guarantee the public's right to know and to manage data related to higher education. In the second step, a survey was used to examine the operation status of general universities.

In 2020, a structured survey paper was distributed to 186 universities operating general graduate schools. Of those 106 (56.7\%) graduate schools responded and participated in the survey. The structured survey paper was made in the form of an Excel file and was completed by e-mail. There are five items on academic operation and management, including the current status of the institution (graduate school), credits required for completion, length of study, minimum attendance criteria for receiving credits, and grade evaluation method.

\section{Research results}

\subsection{Analysis of the overall status of general graduate students}

A comparison of general graduate schools in 2008 and 2020 show a $20 \%$ increase in the number of graduate schools from 154 to 186 . While the number of freshmen students increased $12.2 \%$ (55,430 to 66,982), graduate students increased $11.6 \%(134,453$ to 156,192$)$, and international students increased $284 \%(9,491$ to 27,028$)$, the rate of student dropout continues to rise.

\subsection{New Student Recruitment Status}

When observing freshmen enrolled in master's programs, the rate of students from the same university was $43.2 \%$, and the rate of students from other universities was $56.8 \%$. 
Table 1. Overview of general graduate student numbers

\begin{tabular}{|c|c|c|c|c|c|c|}
\hline \multicolumn{2}{|c|}{ School Type } & 2008 & 2011 & 2014 & 2017 & 2020 \\
\hline \multicolumn{2}{|c|}{$\begin{array}{c}\text { No. Of General Graduate } \\
\text { Schools }\end{array}$} & 154 & 170 & 177 & 184 & 186 \\
\hline \multirow{3}{*}{$\begin{array}{l}\text { Freshmen } \\
\text { Status }\end{array}$} & $\begin{array}{l}\text { Entrance } \\
\text { Capacity }\end{array}$ & 56,430 & 58,988 & 63,437 & 63,810 & 64,261 \\
\hline & No. Enrolled & 55,032 & 62,086 & 65,057 & 62,792 & 66,982 \\
\hline & $\begin{array}{c}\text { Freshmen } \\
\text { Recruitment } \\
\text { Rate }(\%)\end{array}$ & 97.5 & 105.3 & 102.6 & 98.4 & \\
\hline \multicolumn{2}{|c|}{ No. Of Students } & 134,453 & 147,062 & 151,991 & 152,039 & 156,192 \\
\hline \multicolumn{2}{|c|}{$\begin{array}{l}\text { No. Of International } \\
\text { Students }\end{array}$} & 9,491 & 14,269 & 15,773 & 18,347 & 27,028 \\
\hline \multirow{2}{*}{$\begin{array}{l}\text { Status of } \\
\text { Dropout } \\
\text { Students }\end{array}$} & $\begin{array}{c}\text { No. Of } \\
\text { Dropout } \\
\text { Students } \\
\end{array}$ & 7,790 & 8,378 & 8,983 & 9,291 & 9,523 \\
\hline & $\begin{array}{l}\text { Dropout } \\
\text { Rate }\end{array}$ & 5.8 & 5.7 & 5.9 & 6.1 & 6.2 \\
\hline
\end{tabular}

Note: As of April of the current year

Table 2. Average number of freshmen recruited by university (master's program)

\begin{tabular}{|c|c|c|c|c|}
\hline Category & $\begin{array}{c}\text { Number of } \\
\text { Universities }\end{array}$ & $\begin{array}{c}\text { Own University } \\
\text { Affiliate }\end{array}$ & $\begin{array}{c}\text { Other University } \\
\text { Affiliate }\end{array}$ & Total \\
\hline $\begin{array}{c}\text { Average No. of Recruited } \\
\text { Freshmen Students by University } \\
\text { (Master's Program) }\end{array}$ & 105 & 117.6 & 154.4 & 272.0 \\
\cline { 3 - 5 } & \multirow{2}{*}{$\begin{array}{c}\text { Average No. of Recruited } \\
\text { Freshmen by University } \\
\text { (Doctoral Program) }\end{array}$} & $(43.2 \%)$ & $(56.8 \%)$ & $(100.0 \%)$ \\
\cline { 2 - 5 } & \multirow{2}{*}{$\begin{array}{c}\text { Average No. of Recruited } \\
\text { Freshmen by University } \\
\text { (Integrated Master's \& PhD. } \\
\text { Program) }\end{array}$} & $(54.3 \%)$ & $(45.7 \%)$ & $(100.0 \%)$ \\
\cline { 2 - 5 } & 51 & $(49.1 \%)$ & 19.3 & 38.0 \\
\hline
\end{tabular}

Note: Calculated based on students enrolled in September 2017 and March 2018 (excluding research students), and the number of recruitment is the average of the number of applicants for each university that submitted the data, including general admission, special screening, undergraduate/master's courses, other screenings, etc.

\subsection{Required credits for completion}

The required credits to complete a graduate program are about 24 to 26 credits for the master's program, about 34 to 40 credits for the doctoral program, and about 54 to 60 credits for the integrated master's and doctoral program. 


\subsection{Class duration}

Among 103 master's programs, 97 graduate schools (94.2\%) operated in four semesters and three graduate schools $(2.9 \%)$ operated in eight semesters. There were two (1.9\%) that operated over six semesters. Overall, the length of study for $94 \%$ of the masters programs operated in four semesters.

Table 3. Required credits for completion

\begin{tabular}{|c|c|c|c|c|c|c|}
\hline \multirow{2}{*}{ Category } & \multicolumn{2}{|c|}{ Master's Program } & \multicolumn{2}{c|}{ Doctoral Program } & $\begin{array}{c}\text { Integrated Master's \& Doctoral } \\
\text { Program }\end{array}$ \\
\cline { 2 - 6 } & $\begin{array}{c}\text { No. of } \\
\text { Universities }\end{array}$ & $\begin{array}{c}\text { Required Credits } \\
\text { for Completion }\end{array}$ & $\begin{array}{c}\text { No. of } \\
\text { Universities }\end{array}$ & $\begin{array}{c}\text { Required Credits } \\
\text { for Completion }\end{array}$ & $\begin{array}{c}\text { No. of } \\
\text { Universities }\end{array}$ & $\begin{array}{c}\text { Required Credits } \\
\text { for Completion }\end{array}$ \\
\hline \multirow{2}{*}{$\%$} & 100 & 24.8 & 96 & 37.1 & 60 & 58.3 \\
\hline
\end{tabular}

Note: The required credits are credits required for completion of each degree program. If the required credits are different for each major, the most required credits are used.

Table 4. Class duration (master's program)

\begin{tabular}{|c|c|c|c|c|c|}
\hline Category & 4 Semesters & 6 Semesters & 8 Semesters & No Limit & Total \\
\hline $\mathrm{N}$ & 97 & 2 & 3 & 1 & 103 \\
\hline$\%$ & $(94.2 \%)$ & $(1.9 \%)$ & $(2.9 \%)$ & $(1.0 \%)$ & $(100.0 \%)$ \\
\hline
\end{tabular}

Among 99 doctoral programs, 63 graduate schools operated in four semesters (63.6\%), and 24 graduate schools $(24.2 \%)$ operated in six semesters. There were six graduate schools (6.1\%) that ran for five semesters. Approximately $64 \%$ of graduate schools operated the doctoral program in four semesters, like the master's program. There was more than $24 \%$ of graduate schools that operated in six semesters.

Table 5. Class duration (doctoral program)

\begin{tabular}{|c|c|c|c|c|c|c|c|c|}
\hline Category & $\begin{array}{c}4 \\
\text { Semesters }\end{array}$ & $\begin{array}{c}5 \\
\text { Semesters }\end{array}$ & $\begin{array}{c}6 \\
\text { Semesters }\end{array}$ & $\begin{array}{c}8 \\
\text { Semesters }\end{array}$ & $\begin{array}{c}10 \\
\text { Semesters }\end{array}$ & $\begin{array}{c}14 \\
\text { Semesters }\end{array}$ & No Limit & Total \\
\hline $\mathrm{N}$ & 63 & 6 & 24 & 2 & 1 & 2 & 1 & 99 \\
\hline$\%$ & $(63.6 \%)$ & $(6.1 \%)$ & $(24.2 \%)$ & $(2.0 \%)$ & $(1.0 \%)$ & $(2.0 \%)$ & $(1.0 \%)$ & $(100.0 \%)$ \\
\hline
\end{tabular}

Among 63 graduate schools offering integrated master's and doctoral programs, $54(85.7 \%)$ graduate schools operated in eight semesters, and three $(4.8 \%)$ were operated in nine semesters. Overall, about $86 \%$ of the study period for the integrated master's and doctoral program is eight semesters. 
Table 6. Class duration (integration master's \& doctoral program)

\begin{tabular}{|c|c|c|c|c|c|c|c|c|}
\hline Category & 7 & 8 & 9 & 10 & 14 & 16 & No Limit & Total \\
\hline $\mathrm{N}$ & 1 & 54 & 3 & 2 & 1 & 1 & 1 & 63 \\
\hline$\%$ & $(1.6 \%)$ & $(85.7 \%)$ & $(4.8 \%)$ & $(3.2 \%)$ & $(1.6 \%)$ & $(1.6 \%)$ & $(1.6 \%)$ & $(100.0 \%)$ \\
\hline
\end{tabular}

The length of study was set at a similar level by establishment, region, and scale without any particular difference, so it was analyzed as being standardized nationwide.

\subsection{Thesis guidance credits}

On giving credit for thesis guidance for master's programs, of the 103 graduate schools, 39 graduate schools $(37.9 \%)$ do not give credits for the thesis guidance for master's courses. Of the remaining graduate schools, $22(21.4 \%)$ grant three credits, $16(16.6 \%)$ awarded two credits, and $15(14.6 \%)$ awarded one credit. There were significant differences between graduate schools in granting credits for thesis guidance for master's programs.

Table 7. Thesis guidance credits (master's program)

\begin{tabular}{|c|c|c|c|c|c|c|c|}
\hline Category & 1 Credit & 2Credits & 3 Credits & 4 Credits & 6 Credits & None & Total \\
\hline $\mathrm{N}$ & 15 & 16 & 22 & 2 & 9 & 39 & 103 \\
\hline$\%$ & $(14.6 \%)$ & $(15.5 \%)$ & $(21.4 \%)$ & $(1.9 \%)$ & $(8.7 \%)$ & $(37.9 \%)$ & $(100.0 \%)$ \\
\hline
\end{tabular}

For the doctoral program, $39(39.3 \%)$ of the 99 graduate schools do not grant credits for thesis guidance. There were $17(17.2 \%)$ graduate schools that awarded three credits, 14 $(14.1 \%)$ that awarded $6,12(12.1 \%)$ granting 2 credits, and 10 graduate schools $(10.1 \%)$ granting one credit. There was a lot of variance between graduate schools granting credits for doctoral thesis guidance.

Table 8. Thesis guidance credits (doctoral program)

\begin{tabular}{|c|c|c|c|c|c|c|c|}
\hline Category & 1 Credit & 2Credits & 3 Credits & 4 Credits & 6 Credits & None & Total \\
\hline $\mathrm{N}$ & 10 & 12 & 17 & 7 & 14 & 39 & 99 \\
\hline$\%$ & $(10.1 \%)$ & $(12.1 \%)$ & $(17.2 \%)$ & $(7.1 \%)$ & $(14.1 \%)$ & $(39.4 \%)$ & $(100.0 \%)$ \\
\hline
\end{tabular}

Out of 57 graduate schools, $19(33.3 \%)$ graduate schools did not grant any credits for thesis guidance for the integrated master's and doctoral programs. Of the remaining graduate schools, there were $11(19.3 \%)$ that granted three credits, and $11(19.3 \%)$ granted six credits. There were six graduate schools $(10.5 \%)$ that gave 2 credits. There was a lot of variation between graduate schools in granting credits for thesis guidance in the integrated master's and doctoral programs. 
Table 9. Thesis guidance credits (Master's PhD)

\begin{tabular}{|c|c|c|c|c|c|c|c|c|}
\hline Category & 1Credit & 2Credits & 3 Credits & 4 Credits & 6 Credits & 9Credits & None & Total \\
\hline $\mathrm{N}$ & 4 & 6 & 11 & 4 & 11 & 2 & 19 & 57 \\
\hline$\%$ & $(7.0 \%)$ & $(10.5 \%)$ & $(19.3 \%)$ & $(7.0 \%)$ & $(19.3 \%)$ & $(3.5 \%)$ & $(33.3 \%)$ & $(100.0 \%)$ \\
\hline
\end{tabular}

Overall, over one third of institutions did not recognize thesis guidance credits, and more than one third of the institutions acknowledged 2-3 credits.

\section{Conclusion}

By observing the student statistics of South Korean graduate schools, it is apparent the rate of undergraduate students entering graduate school has decreased. For the students that enter graduate school, there is the issue of a large number of students dropping out of the program (the dropout rate increased from 5.8\% in 2008 to 6.2\% in 2020). There is a need for new efforts and strategies to assist and support dropout graduate students to complete their degrees [11][12]. The process of obtaining a degree should be carefully analyzed in order to create an environment for students to successfully complete a degree program.

The number of international students is increasing rapidly in Korean graduate schools. In order to attract top students from abroad, it is necessary to develop and invest in programs for international students nationwide. Additionally, in order to innovate and elevate graduate education to a global standard, the admissions requirements and conditions need to be strengthened [13].

In order to improve the quality of graduate schools in the future, it is necessary to consider increasing the credits required for graduation. Currently, the credit requirement for general graduate schools in South Korea is 24 credit requirements for a master's degree and 36 credits for a doctorate degree. This is significantly insufficient compared to countries that operate course-based degree programs such as the United States. Graduate schools in the United States operate in an autonomous system for each graduate school. In other words, the admission procedure, curriculum, the amount of time taken to complete the degree, credits requirements, and degree requirements vary depending on the university and major. However, in general, the required credits and time frame for completion for a master's degree is 30 to 60 credits over 1 to 2 years, and 60 to 80 credits over 3 to 5 years to obtain a doctoral degree. It is necessary to strengthen conditions of graduation by raising the requirement level to 30 credits for the master's program, by raising the credit requirements for the doctoral program, and by creating additional conditions (writing journal submissions, etc.).

In September 2020, the South Korean Ministry of Education announced changes in academic management following the outbreak of COVID-19. From 2021, South Korean universities no longer require students to be physically present on campus for a set period of time, and will allow students to acquire bachelor's and master's degrees through distance learning in joint degree programs with overseas universities. Therefore, based on the discussions on academic operation and management of graduate schools reviewed in this study, a follow-up study should be conducted by domestic graduate schools to expand joint degree programs after COVID-19 with graduate schools abroad. 


\section{References}

[1] Hyun-Seok Shin, "Exploring a vision and policy measures for future graduate school system", The Korea educational review, vol.17, no.1, pp.156-192, (2011)

[2] Hyun-Seok Shin, and Sang-Jin Ban, Seok-Yul Lee, "An analysis of graduate educational system in major foreign countries: some implications for educational policy," Korean Journal of Comparative Education, vol.15, no.2, pp.53-86, (2005)

[3] Ho-Jun Lee, Min-Seok Yang, Hyun-Kook Lee, Ji-Hye Jeong, Ji-Eun Yoo, and Dong-Wook Jeong, “An analysis of return to education of graduate school among nations," Korean Journal of Comparative Education, vol.23, no.4, pp.161-183, (2014)

[4] Seung-Jung Kim, "Characteristics of research and education in doctoral education by academic discipline," The Journal of Educational Administration, vol.35, no.2, pp.227-251, (2017)

[5] Sang-Jin Ban, Hyun-Seok Shin, Seok-Yeul Lee, Eun-Ku Lee, Gyum-Hoon Kim, and Byung-Jae Min, "Enhancing quality in graduate school," The Journal of Educational Administration, vol.22, no.2, pp.255277, (2004)

[6] Hyun-Seok Shin, Eun-Ku Lee, Gyum-Hoon Kim, and Myeong-Soon Roh, "Factors that influence satisfaction with the quality of graduate education," Journal of research in education, vol.0, no.31, pp.49-77, (2008)

[7] Hyun Seok Shin, "An analysis on graduate school information disclosure system and its alternatives for development," The Korea educational review, vol.21, no.1, pp.139-170, (2015)

[8] Kwang-Tae Song, Chung-Hyun Chung, and Hee-chang Park, "Study on the satisfaction survey in graduate school," Journal of the Korean Data Analysis Society, vol.13, no.5, pp.2343-2352, (2011)

[9] Jung-mi Lee, and Gil-jae Lee, "A study on the factors associated with students' satisfaction with graduate education," The Journal of Educational Administration, vol.36, no.2, pp.229-251, (2018)

[10] Jin-Young Lee, Kang-Hyun Park, and Bi-a Kim, "The structural relationship between environmental and educational factors of graduate school and satisfaction with graduate school," Journal of Educational Innovation Research, vol. 29, no.4, pp.265-282, (2019) DOI:10.21024/pnuedi.29.4.201912.265

[11] Jeongmi Lee, Deokho Jang, Kyunghee Han, Giljae Lee, Sohyun Lim, "The reality and development direction of education for the next generation of academics," Challenges and innovations in graduate education. Korean Educational Administration Association, Korean Educational Administration Association Fall Conference. pp.41-86, (2018)

[12] Sukyeol Lee, Younghak Lee, and Jincheol Jung, "Analysis of the current situation and basic research for establishing an innovation plan for graduate school," Sejong: Ministry of Education, (2019)

[13] Min Kyung-chan, "The vision and direction of innovation for graduate school development," Challenges and innovations in graduate education. Korean Educational Administration Association, 2018 Korean Educational Administration Association Fall Conference, pp.3-37, (2018) 
This page is empty by intention. 